\title{
Durability and Water Stability of Pellet Fish Supplementation Results pairing Coconut Oils and Hazlenut Oil
}

\author{
Kiki Haetami ${ }^{1}$, Junianto ${ }^{1}$, Iskandar ${ }^{1}$, Rita Rostika $^{1}$, Abun $^{2}$
}

\begin{abstract}
${ }^{1}$ Faculty of Fisheries and Marine Science, Padjadjaran University, ${ }^{2}$ Faculty of Animal Husbandry, Padjadjaran University, Street Bandung-Sumedang KM. 21, 45363, Sumedang-West Java, Indonesia, (phone) +6222 7798241, (fax) +6222 7798212
\end{abstract}

\begin{abstract}
Fish cultivation encourages increased demand for artificial feed, but information on nutritional fulfillment of pellets provided is limited. Supplementof oil in fish feeds can function to increase the energy content and as a neutral fat tangible liquid at room temperature should be noted the effect on the physical quality of fish pellets. In contrast to natural food, the physical quality of feed formulation is important in fish farming given its susceptibility to pellet degradation and leaching nutrients.

Six treatmentsincluding controlwith three replicates with setup different of used of oil (coconut and candlenut oil supplement) and added Se (basal diets;mixed of oil without and added Se, coconut oil; candlenut oil added Se, and control pellet with high protein content) informulated. The type of tested feed was dry compressed pellet using pelletizer. Pellet leaching rates were used to indicate pellet water stability.

The results showthat the presence of vegetable oil supplement in the diets significantly improved pellet water stability ( $p<0.05$ ), but theuse of fat into the pit resulted in the same durability as the control diets. Used of oil supplement have higher water stability after two hours in water compared to basal pellets without fat supplements. It improved feeds water stability is one important reason why oil supplement enhances fish growth.
\end{abstract}

Keywords-Durability, Stability, Coconut and Candlenut Oil Supplement, Nile Pellet.

\section{INTRODUCION}

Quality of pellets is one of the feed factors that can affect the performance of fish. This is because the purpose of feeding is the utilization of nutrients, while the fish live in water so as to enablethe occurrence of leaching. Degradation of pellets is a measure of the quality of physical pellets in fish feeds known from the durability and stability of the pellets in water. Pellet durability is

$\underline{\text { www.ijeab.com }}$ associated with a dusty effect (fine), since the accumulation of pellet destruction will affect fish weight and feed conversion.

According to Chem and Jenn (1992), pellet stability, density, composition, and supplementation effects are the main factors determining the physical characteristics of pellets in fish feed. Furthermore, according to Jayaram and Shety (1981), the stability of the feed formulation is influenced by the composition of the feed, the type of processing, and moisture content. According Rasyaf (1994), the use of oil as part of the formulation usually only ranges from 1-3\%, because if excessive can cause the pellets back into the form of flour. Meanwhile, according to Behnke (2001), the addition of fat in high quantities more than $10 \%$ can inhibit starch gelatinization. Voragen (1995) states that Rheological properties or processes such as gelation or attachment and other properties (adhesion and cohesion) affect the formation of textures. Walter (1990) states that the fat lubrication effect on the die surface of the pellet mold causes the oil or wax to accumulate at the attachment site to create a binding effect through the necking as part of the mold. Although it can improve texture, fat as a hydrophobic compound may interfere with the binding of the water soluble component in feed (starch, protein and fiber) so that it can be detrimental to hardness and endurance of feed.

\section{MATERIALS AND METHODS}

The raw materials used consist of soybean meal, fish meal, polar and rice bran, and carboxy methyl cellulose. While the fat supplements used are vegetable oil from coconut and kemiri. The preparation of an oil supplement is carried out by an unheated extraction method using a coconut water solvent (coconut oil) and a hexane solvent (hazelnut oil). Before formulated, all feed ingredients are analyzed proximate first. The pellet is formulated with a protein 
content of about 28 percent, with a control protein of 32 percent with a formulation arrangement in Table 1. Pellet preparation is printed using a pelletizer with a diameter of 3 $\mathrm{mm}$ and $50-70^{\circ} \mathrm{C}$ drying in the dryer for two days. Dry pellets are then packed in plastic bags and stored at room temperature to be tested for their physical qualities through durability and stability measurements.

Table.1: Composition of Feed Material for each Treatment

\begin{tabular}{rlrrrrrr}
\hline \multirow{2}{*}{ No } & \multicolumn{1}{c}{ Raw Material } & \multicolumn{1}{c}{$\mathrm{R}_{1}$} & \multicolumn{1}{c}{$\mathrm{R}_{2}$} & \multicolumn{1}{c}{$\mathrm{R}_{3}$} & \multicolumn{1}{c}{$\mathrm{R}_{4}$} & \multicolumn{1}{c}{$\mathrm{R}_{5}$} & $\mathrm{R}_{\mathrm{K}}$ \\
& & \multicolumn{2}{c}{$\ldots \ldots \ldots \ldots \ldots \ldots \ldots \ldots \ldots \ldots \ldots \ldots \ldots \ldots \ldots \ldots \ldots \ldots \ldots \ldots \ldots \ldots \ldots \ldots \ldots \ldots \ldots$} \\
\hline 1 & Soybean meal & 29.00 & 30.00 & 30.00 & 30.00 & 30.00 & 33.50 \\
2 & Fish meal & 10.00 & 10.50 & 10.50 & 10.50 & 10.50 & 12.00 \\
3 & Rice bran & 18.00 & 18.00 & 18.00 & 18.00 & 18.00 & 18.00 \\
4 & Corn meal & 14.00 & 1.00 & 1.00 & 1.00 & 1.00 & 9.50 \\
5 & Blood meal & 3.50 & 2.00 & 2.00 & 2.00 & 2.00 & 6.00 \\
6 & Coconut meal & 7.50 & 7.50 & 7.50 & 7.50 & 7.50 & 8.00 \\
7 & Pollard & 10.00 & 19.00 & 19.00 & 19.00 & 19.00 & 5.00 \\
8 & CMC & 2.00 & 2.00 & 2.00 & 2.00 & 2.00 & 2.00 \\
9 & CaCO3 & 2.00 & 2.00 & 2.00 & 2.00 & 2.00 & 2.00 \\
10 & Bone meal & 2.00 & 2.00 & 2.00 & 2.00 & 2.00 & 2.00 \\
11 & Premix & 2.00 & 2.00 & 2.00 & 2.00 & 2.00 & 2.00 \\
12 & Coconut Oil & 0.00 & 2.00 & 2.00 & 4.00 & 0.00 & 0.00 \\
13 & Hazlenut oil & 0.00 & 2.00 & 2.00 & 0.00 & 4.00 & 0.00 \\
\hline & & 100 & 100 & 100 & 100 & 100 & 100 \\
& Selenit & 0 & 0 & 0,0015 & 0,0015 & 0,0015 & 0 \\
& Crude Protein (\%) & 28.07 & 28.14 & 28.14 & 28.05 & 28.05 & 32.05 \\
& DE (kcal/kg) & 2237 & 2248 & 2248 & 2250 & 2250 & 2246 \\
& Extract Ether (\%) & 5.33 & 9.21 & 9.21 & 9.21 & 9.21 & 5.27 \\
\hline
\end{tabular}

Determination of Stability of Pelleted Feeds: The water stability of the pellets was d glass beakers, which contained $800 \mathrm{ml}$ tap water. The determined over a period of 6 hours by wet durability test with considerable modification to suit the present situation. Triplicate 5 grams samples of pellet of each diet were dropped into 15 immersion times examined were $1 \mathrm{~h}, 2 \mathrm{~h}, 4 \mathrm{~h}$ and $6 \mathrm{~h}$ water were filtered through filter paper and were dried in the oven $\left(105^{\circ} \mathrm{C}\right.$ for $\left.30 \mathrm{~min}\right)$, followed by further drying at $65^{\circ} \mathrm{C}$ to a constant weight, then cooled in a desiccators. The mean differences in weights of beakers containing the feed before immersion and after drying were used to calculate. The percentage dry matter loss, which is a measure of the water stability of the pellets for the corresponding time intervals.

$$
\text { Leaching rate } x=\frac{\mathrm{A} \times(1-\mathrm{r})-\mathrm{R}}{\mathrm{A} \times(1-\mathrm{r})} \times 100
$$

where,

A $=$ Weight of pellets before immersion;

$\mathrm{r}=$ Moisture content of pellets; and

$\mathrm{R}=$ Dry weight of the remaining solid.

\section{RESULTS AND DISCUSSION}

The sluggish feeding habit of Carp and tilapia fish species, making the measurement of pellet stability in water is necessary at least after an hour in water (Jayaran, 1978). The low stability of the pellets in water causes an imbalance in the aquatic medium, however, the high pellet dispersion value is also unfavorable in terms of production costs and the availability of bound nutrients (Renukaradhya and Varghese, 1987). The pellet stability number in water after soaking 30 minutes, 60 minutes and 120 minutes is presented in Table 2and can also be shown in Figure 1. 


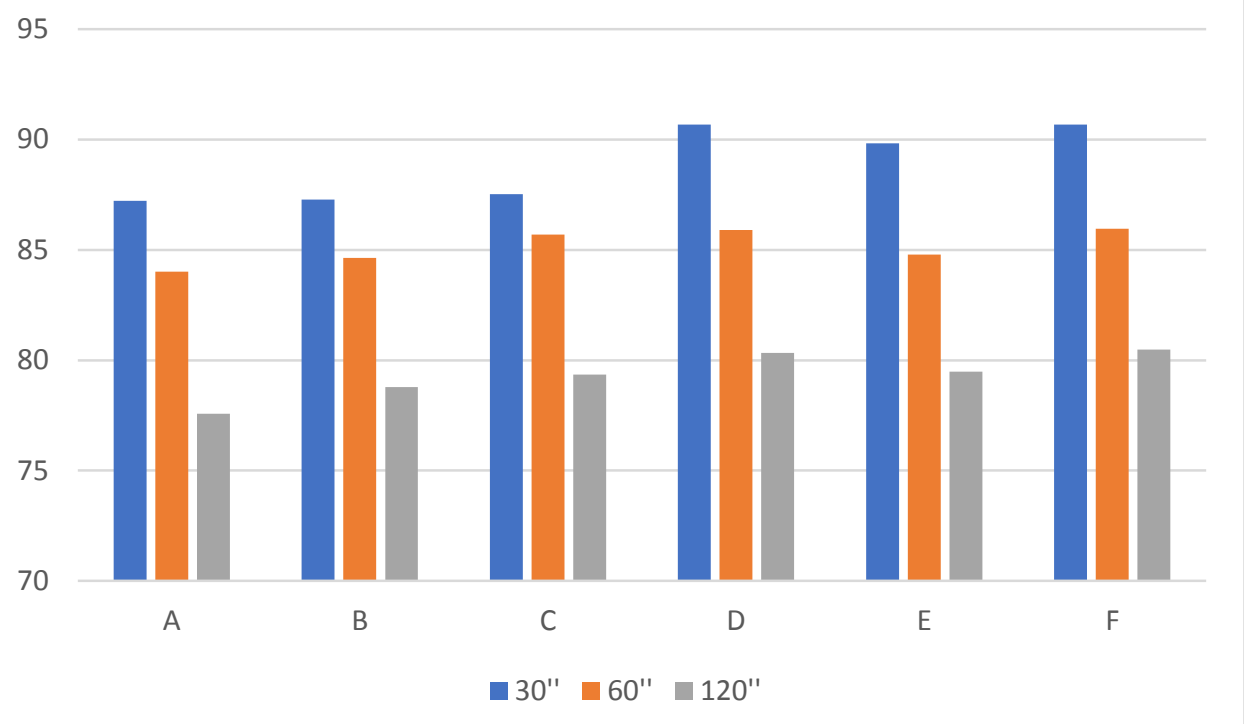

Fig.1: Dispersion Graph Pellet in water after 30 minutes, 60 minutes and 120 minutes

The graph shows that, the treatment of fat supplementation tends to increase the stability of the pellets in water. Galli (2000) states that additional feed additives can improve the quality of pellets by adding moisture and surfactant technologies either to the process before pelleting (mixing) or after pelleting (during cooling or conditioning).) Humidity is required as a conductive medium Transfer) heat into the feed particles so that the fat can seep into the feed at a faster rate. While incorporation of the surfactant allows much faster permeation of the feed particles during the pelletizing process thereby reducing the surface tension of the water.The surfactant and the heat are at a certain time or called At the glass transition point causes the fat trapped into the feed particles, so this does not cause the pellet to look oily.

Variance analysis showed differences between treatment and Duncan Test results (Table 2) showed that fat supplements in the formulation may affect the physical quality of the pellets.

Table.2: Physical Quality of Pellets (Durability and Stability)

\begin{tabular}{|c|ccc|c|c|}
\hline \multirow{2}{*}{ Treatments } & \multicolumn{2}{|c|}{ Durability } & \multicolumn{3}{|c|}{ Water Stabilityof Pelletsin Water } \\
\cline { 3 - 6 } & & & 30 minutes & 60 minutes & 120 minutes \\
\hline $\mathrm{R}_{1}$ & 89,00 & $\mathrm{~b}$ & 87,22 & 84,01 & $77,57 \mathrm{~b}$ \\
\hline $\mathrm{R}_{2}$ & 89,50 & $\mathrm{ab}$ & 87,27 & 85,15 & $78,79 \mathrm{ab}$ \\
\hline $\mathrm{R}_{3}$ & 89,67 & $\mathrm{ab}$ & 87,53 & 85,70 & $79,35 \mathrm{a}$ \\
\hline $\mathrm{R}_{4}$ & 90,67 & $\mathrm{a}$ & 90,67 & 85,90 & $80,33 \mathrm{a}$ \\
\hline $\mathrm{R}_{5}$ & 89,83 & $\mathrm{ab}$ & 89,83 & 84,79 & $79,49 \mathrm{a}$ \\
\hline $\mathrm{R}_{6}$ & 90,67 & $\mathrm{a}$ & 90,67 & 85,96 & $80,49 \mathrm{a}$ \\
\hline
\end{tabular}

Table 2 shows that pellet control $\left(\mathrm{R}_{6}\right)$, and pellets with coconut oil supplement $\left(\mathrm{R}_{4}\right)$ have higher durability values than basal pellets $\left(\mathrm{R}_{1}\right)$. Pellets with higher protein content (control pellets) are better than those of basalt pellets. The durability of pellets containing these higher proteins is related to the nature of protein flexibility in various reactions. According to Thomas (1998), plasticizes protein and starch structure disruption process is the cause of starch gelatinization in the pellet-making process involving thermal, chemical and mechanical energy conditions.

The addition of fat supplements of the type of coconut oil $\left(\mathrm{R}_{4}\right)$ which produces the highest durability compared to other types of oil although not significantly different. Coconut oil supplementation in basal feed formulations (low protein) can increase durability as well as high protein pellets. Theuse of coconut oil is more resistant to rotation of the tumbling device, due to its more saturated and non- 
volatile structure, will soon close the pores of the cell wall matrix and act as a lubricant between the feed particles, as well as the heat conductor. This will have a positive effect on violent pellets. Coconut oil is one of the vegetable products that contain a lot of saturated fatty acid that is equal to $92 \%$, while kemiri contains many unsaturated fatty acid and tend to be volatile. Volatile fatty acids are fatty acids such as linoleic, linolenic, stearate, oleic, and others that are not bound by glyceride molecules.

The addition of the hazelnut oil supplement $\left(\mathrm{R}_{5}\right)$ and the coconut mixture $\left(\mathrm{R}_{3}\right)$ produced the same effect as the other treatments, including with the basalt pellet $\left(\mathrm{R}_{1}\right)$. The presence of carboxy-methyl-cellulose binder (CMC) in the feedstock arrangement in all treatments also affects durability. The value of the durability of pellets with coconut oil supplements (feed $\mathrm{R}_{4}$ ) produces durability that is not different from the control pellets, as well as the pecan oil supplement and the hazelnut oil mixture. The results of this study of selenium use were not expected to affect the physical quality of pellets, it is seen in the durability value of coconut oil mixture and hazelnut with addition of $\mathrm{Se}\left(\mathrm{R}_{3}\right)$ which is not different with without selenium $\left(\mathrm{R}_{2}\right)$. The durability value of oil addition treatment by $4 \%$ in this study ranged from 89 to $90.67 \%$. Pellet durability is of good quality if the durability value is above $80 \%$ (Dozier, 2001) whereas according to Briggs, et al. (1999) is over 90\% and the optimum pellet quality should have a resistance index above $96 \%$.

Table 2 shows that the dispersion or stability value of pellets in water after 30 minutes of soaking did not show any difference as well as the analysis of variance versus pellet dispersion after immersion for 60 minutes, whereas after 120 minutes the basal pellets had low stability. In this study,the use of $2 \% \mathrm{CMC}$ binder also affects pellet stability up to 60 minutes. The high polarity or energy interaction between the polysaccharide chains in CMC and the ionic liquid phase increases the stability of the pellets in water.

The control pellet $\left(\mathrm{R}_{6}\right)$ produces the highest stability, although not unlike the oil-added pellets, until 60 minutes of immersion. The high stability in this control pellet, in accordance with Thomas (1998) statement, that the properties of proteins in the processing in addition to sensory and kinesthetic aspects (such as flavor, odor, color, texture); Also includes aspects of hydration, dispersibility, solubility and swelling. Behnke (2001), a substitution of $10 \%$ cassava starch with wheat gluten containing higher protein in catfish pellets showed increased stability.

The use of vegetable fat supplements of $4 \%$ both coconut oil and hazelnut oil on the results of this study has no effect on the dispersion of pellets in water up to an hour in the water. At the 120 minutes measurement, control pellets and pellets with oil supplements were more stable in water $(78.79 \%-80.49 \%)$. Feed formulations with proteins of $20 \%$, $30 \%$, and $40 \%$ were supplemented with higher fat content (about 7\%), had higher stability than pellets containing $45 \%$ protein (Renukaradhya and Varghese (1987). Only helps the formation of more compact pellets, can also prevent the penetration of water, so it can be maintained its compact texture in a longer time.

Table 2 shows that at the same protein content, the pellets without the use of supplements (basal feed) had a lower pellet dispersion value than the treatment containing $4 \%$ oil supplement (treatment $\mathrm{R}_{2}, \mathrm{R}_{3}, \mathrm{R}_{4}$ and $\mathrm{R}_{5}$ ). With the same feed ingredients composition as the basalt pellets, more fat in the treatment with oil supplements can maintain the texture of the pellet's texture up to two hours in the water. The addition of fat closes the pores of the cell wall matrix so that it can act as a lubricant between the particles (mash) feed, as well as the heat conductor. Mixing water and fat is present in the optimal amount of bonds set by wax and fat on one side and water on the other and this will have a positive effect on the pellet's hardness and pellet durability in water.

The process of making pellets in this study using a dry pelletizer tool without the addition of steam (high temperature) as in the extruder process. The value of pellet stability in water after one hour of immersion in the results of this study ranged from 84.01 to 85.96 , and after two hours of $77.57-80.49 \%$. Compared to the results of research of Renukaradhya and Varghese (1987), goldfish pellets can maintain their stability after one hour in the water that is $89.56 \%-90.56 \%$ because it uses steam in the manufacturing process. The result of Ighwela (2013) study, pellet with 5\% fat content, maltose $0-35 \%$ level treatment, has stability value after one hour $77,83-90,33 \%$ and $74,30-85,93 \%$ after two hours of immersion. Pellets with high water stability, allow feeding (period period) and transit time in the intestine can be extended, although it can decrease consumption. When it comes to leaching nutrients, the smaller the stability, the more likely the nutrients are released in the water. According to Meyer (2001), tilapia pellet (Oreochromisniloticus) occurs degradation of pellets and leaching protein and lipids by $25 \%$ within 2 hours in water. Thus, the physical properties of the feed are related to nutritional value in the feeding process, but more information is needed both on the scale of the study and in commercial fish farming. 


\section{CONCLUSION}

Used of oil supplement have higher water stability after two hours in water compared to basal pellets without fat supplements. It improved feeds water stability is one important reason why oil supplement enhances fish growth.

\section{REFERENCES}

[1] Behnke, K.C. 2001. Factors Affecting Pellet Quality. Maryland Nutrition Conference, Department of Poultry Science and Animal Science, University of Maryland. Feed Tech.cbna.com.br.

[2] Briggs, J.L., D.E. Maier, B.A. Watkins, K.C. Behnke. 1999. Effects of Ingredients and Processing Parameters on Pellet Quality. Poultry Sci, 78:14641471.

[3] Budijantoet al., 2001 5: 211-217

[4] Chen H.Y. and J.S. Jenn, 1992. Increased pellet water stability by the supplementation of phospholipid and its effects on shrimp growth. Asian Fisheries Science, 5: 211-217.

[5] Dozier, W.A. 2001. Pellet Quality for Most Economical Poultry Meat. Feed Management 52(2). Watt Publishing Co, MT Morris III.

[6] Galli, J.A. 2000. Technology of the Use of Fats in Feeds. NRA print. Singapore.

[7] Ighwela, K.A., A. Ahmad and A.B. Abol-Munafi, 2013. Water Stability and Nutrient Leaching of Different Levels of Maltose Formulated Fish Pellets. Global Veterinaria 10 (6): 638-642, 2013

[8] Jayaram, M.G. and H.P.C. Shetty, 1981. Formulation, processing and water stability of two new pelleted fish feeds. Aquaculture, 23: 355-359. Aquaculture, 23, 355.

[9] Khalil, 1999a. Pengaruhkandungan air danukuranpartikelterhadapsifatfisikpakanlokal.

Kerapatan Pemadatan Tumpukandan BeratJenis. Media Peternakan, 22 (1): 1-11. Mawar, 1985

[10] Li, A.Y., M Bordinhon, D. A. Davis, W, Zhang, and X. Zhu. 2012. Protein: Energy Ratio In Practical Diets for Nile Tilapia (Oreochromisniloticus). Received: 31 January 2012 /Accepted: 26 November 2012 Ó Springer Science Business Media Dordrecht 2012

[11]Meyer. 2001. Simposio Centro Americano de Acuacultura Proceedings: Tilapia Sessions, 22-24 August 2001. Tegucigalpa, Honduras, pp: 61-70.

[12] Rasyaf, M. 1994. MakananAyam Broiler. Kanisius, Yogyakarta.
[13] Renukaradhya and Varghese. 1987. Formulation, Processing, and Water Stability of Pelleted Feeds with Varying Levels of Protein Used in Carp Nutrition Studies. Pelleted Feed for Carp. Fishery Technology; Vol 24, 1987. 119-121.

[14] Thomas, M. 1998. Physical quality of pelleted feed. A feed model study. In Schokker, Arnhem. PhDthesis. Wageningen Agricultural University, Wageningen Institute of Animal Sciences, Section Animal Nutrition, Wageningen, The Netherlands. BibliotheekLandbouwUniversiteitWageningen ISBN 90-5485-872-9.

[15] Voragen, A.G.J., Gruppen, H., Marsman, G.J.P. and Mul, A.J., 1995. Effect of some manufacturing technologies on chemical, physical and nutritional properties of feed. In: Recent Advances in Animal Nutrition, University of Nottingham. Eds. P.C. Garnsworthy and D.J.A. Cole, Feed Manufacturers Conference 1994, Nottingham University Press, pp 93126. 